\title{
PAPARAN ORGANOFOSFAT KRONIK SEBAGAI FAKTOR RISIKO GANGGUAN KOGNITIF BERDASARKAN KADAR PHOSPHORYLATED TAU SERUM
}

\author{
CHRONIC ORGANOPHOSPHATE EXPOSURE AS A RISK FACTOR OF \\ NEUROCOGNITIVE IMPAIRMENT THROUGH HIGH LEVEL OF \\ PHOSPHORYLATED TAU SERUM
}

Ni Luh Putu Dirasandhi Semedi Putri, * Anak Agung Ayu Putri Laksmidewi, * I Made Oka Adnyana*

\begin{abstract}
Introduction: Chronic organophosphate exposure is predicted related to decreased of neurocognitive function, but the mechanism is still unclear. One possible mechanism is abnormal tau protein metabolism as measured in the serum.

Aims: To measure the role of chronic organophosphate exposure causing neurocognitive impairment through high serum levels of phosphorylated tau protein ( $p$-tau).

Methods: This case control study was conducted in Penarukan Village, Tabanan, Bali from July 2018 to January 2019. This study involved farmers aged 40-60 years who used organophosphates pesticide for at least the last 2 years and did not wear any personal protective equipment during pesticide use. Neurocognitive function was evaluated using Mini Cog Test. The level of p-tau was measured by taking a 2 mililiters of blood sample and analyzed using enzyme-linked immunosorbent assay (ELISA) method.

Results: Sixty six (case = 33; control = 33) subjects were enrolled. Exposure to pesticides for $\geq 10$ years had a higher risk for neurocognitive impairment than $<10$ years (odds ratio 16.675; 95\% CI 4.626-60.105). The receiver operating characteristic (ROC) curve showed normal limit of serum p-tau protein level was $78.67 \mathrm{ng} / \mathrm{L}$. Serum p-tau protein level $\geq 78.67 \mathrm{ng} / \mathrm{L}$ increased the risk for neurocognitive impairment (Odds ratio 20.8; 95\% CI 2.524-171.440). The results of the path analysis found the strength of organophosphate exposure on neurocognitive function through high serum p-tau protein levels was $6.2 \%$.
\end{abstract}

Discussions: Chronic exposure to organophosphate increased the risk of neurocognitive impairment partially mediated by high level of serum p-tau protein.

Keywords: chronic exposure, neurocognitive impairment, organophosphate, phosphorylated tau protein serum.

\section{ABSTRAK}

Pendahuluan: Paparan organofosfat kronik diperkirakan berhubungan dengan penurunan fungsi kognitif, tetapi mekanismenya belum jelas. Salah satu mekanisme yang diprediksi berperan adalah gangguan metabolisme protein phosphorylated tau (p-tau) yang dapat diukur kadarnya dalam serum.

Tujuan: Mengukur peranan paparan organofosfat kronik dalam meningkatkan risiko gangguan fungsi kognitif berdasarkan kadar p-tau serum.

Metode: Penelitian ini merupakan studi kasus kontrol di Desa Penarukan, Tabanan, Bali pada bulan Juli 2018 hingga Januari 2019. Subjek adalah petani berusia 40-60 tahun yang menggunakan organofosfat minimal 2 tahun terakhir tanpa menggunakan alat pelindung diri. Fungsi kognitif diperiksa menggunakan tes Mini-Cog. Kadar p-tau serum diukur dengan mengambil $2 \mathrm{~mL}$ sampel darah dan dianalisis dengan metode enzyme-linked immunosorbent assay (ELISA).

Hasil: Penelitian ini melibatkan 66 subjek penelitian (33 kasus dan 33 kontrol). Paparan pestisida selama $\geq 10$ tahun berisiko lebih tinggi mengalami gangguan fungsi kognitif dibandingkan dengan paparam $<10$ tahun (RO 16,675; IK 95\% 4,626-60,105). Kurva ROC menunjukkan batas nilai normal kadar p-tau 78,67ng/L. Kadar serum p-tau $\geq 78,67 \mathrm{ng} / \mathrm{L}$ meningkatkan risiko gangguan neurokognitif (RO 20,8; IK95\% 2,524-171,440). Hasil analisis jalur kausal didapatkan kekuatan pengaruh paparan organofosfat terhadap fungsi kognitif melalui kadar protein p-tau serum yang tinggi sebesar $6,2 \%$.

Diskusi: Paparan organofosfat kronik meningkatkan risiko gangguan fungsi kognitif yang dimediasi secara parsial oleh kadar protein p-tau serum yang tinggi.

Kata kunci: Gangguan kognitif, organofosfat, paparan kronik, protein p-tau serum

*Departemen Ilmu Penyakit Saraf FK Universitas Udayana/RSUP Sanglah, Denpasar. Korespondensi: okaadnyanadrsps@yahoo.com. 


\section{PENDAHULUAN}

Fungsi kognitif dipengaruhi oleh beberapa aspek, seperti biologis, sosial ekonomi, aktivitas kognitif, serta lingkungan. ${ }^{1-2}$ Salah satu aspek lingkungan yang diperkirakan berpengaruh terhadap fungsi kognitif adalah paparan pestisida, ${ }^{3-4}$ walapun patofisiologi terjadinya gangguan tersebut masih menjadi perdebatan. Efek paparan kronik pestisida dengan dosis rendah sampai sedang terhadap status kesehatan pengguna pestisida belum banyak diteliti. ${ }^{4-5}$ Beberapa penelitian menunjukkan hasil yang tidak konsisten dan kontroversial.

Sebuah studi meta analisis oleh Munoz-Quezada pada 1256 artikel menyimpulkan adanya asosiasi antara paparan kronis pestisida jenis organofosfat dengan penurunan fungsi kognitif pada pekerja yang terpapar pestisida. Domain fungsi kognitif yang dilaporkan terganggu adalah fungsi eksekutif, kecepatan berpikir, atensi, memori verbal, dan memori visual. ${ }^{4}$ Suatu uji eksperimental dilakukan dengan memberikan pestisida deltamethrin dan carbofuran pada tikus sekali sehari selama 28 hari kemudian dilakukan pengecekan imunohistokimia. Hasil penelitian ini menunjukkan paparan pestisida menyebabkan penurunan protein sinaptik n-methyld-aspartate receptor 1 (NR 1), synaptophysin, dan synapsin 1, serta gen cAMP related element binding (CREB). Paparan pestisida juga menunjukkan menurunnya sel neuron di hipokampus dan korteks, menstimulasi hiperfosforilasi protein tau, aktivasi glycogen synthase kinase-3 $b$ (GSK-3 b), dan inhibisi protein fosfatase-2A (PP)-2A. ${ }^{4}$

Berdasarkan patofisiologi tersebut, dapat dilakukan pengecekan penanda biologis yang bermanfaat untuk mendeteksi gangguan fungsi kognitif subklinis. Salah satu penanda biologis yang diprediksi berperan adalah kadar phosphorylated tau (p-tau) serum, yaitu kadar protein tau yang mengalami hiperfosforilasi. Sebuah penelitian kasus kontrol pada 66 pensiunan pekerja yang terpapar pestisida aluminium menunjukkan $24 \%$ pekerja mengalami gangguan kognitif dan peningkatan kadar protein tau serta p-tau serum. ${ }^{4}$ Protein tau memiliki perbedaan struktur molekuler dengan protein tau yang telah terfosforilasi (p-tau). Di lain pihak, terdapat penelitian yang menyatakan bahwa kadar protein tau plasma pada individu yang mengalami penurunan fungsi kognitif justru mengalami penurunan dibandingkan dengan individu dengan fungsi kognitif normal. ${ }^{4}$

Paparan pestisida menjadi penting untuk diteliti mengingat pertanian merupakan sektor perekonomian yang penting, dipropinsi Balikhususnya dan Indonesia pada umumnya. ${ }^{6}$ Peningkatan pertanian berkorelasi dengan peningkatan penggunaan pestisida sebagai suatu keharusan untuk mempertahankan kualitasnya. ${ }^{7}$ Namun hal ini tidak disertai dengan pengetahuan petani tentang penggunaan pestisida. Penelitian oleh Yuantari dkk menunjukkan pengetahuan petani terkait penggunaan pestisida yang masih rendah. ${ }^{7}$

Penggunaan pestisida yang tinggi, kemungkinan penurunan kualitas hidup akibat gangguan fungsi kognitif, serta data penelitian yang masih terbatas terkait paparan pestisida dan fungsi kognitif merupakan hal yang perlu ditelusuri lebih lanjut. Jenis pestisida yang diteliti adalah organofosfat karena merupakan jenis pestisida yang paling banyak digunakan. Penelitian ini bertujuan untuk mengevaluasi besarnya risiko kejadian gangguan fungsi kognitif pada pengguna pestisida organofosfat kronik dihubungkan dengan kadar p-tau serum. Pengukuran kadar p-tau serum diharapkan dapat menggambarkan gangguan kognitif akibat apapran organofosfat kronis, sehingga berpotensi menjadi prediktor yang reliabel.

\section{TUJUAN}

Mengukur peranan paparan organofosfat kronik terhadap risiko gangguan fungsi kognitif berdasarkan kadar p-tau serum.

\section{METODE}

Penelitian ini merupakan studi kasus kontrol tidak berpasangan yang dilaksanakan di Desa Penarukan, Kecamatan Kerambitan, Kabupaten Tabanan pada bulan Juli 2018 hingga Januari 2019. Kriteria inklusi adalah petani berusia 40-60 tahun yang telah terpapar pestisida organofosfat secara langsung tanpa menggunakan alat pelindung diri selama minimal 2 tahun terakhir. Adapun kriteria eksklusi antara lain, memiliki riwayat intoksikasi akut pestisida, riwayat stroke, epilepsi, tumor otak, parkinson, demensia, penyakit neuromuskular, penyakit 
ginjal, penyakit hati, penyakit jantung, hipertensi, dan diabetes melitus. Kriteria eksklusi dievaluasi berdasarkan anamnesis, pemeriksaan fisik, dan penelusuran rekam medis (bila tersedia) oleh dokter. Subjek dikelompokkan menjadi kelompok kasus dan kelompok kontrol, yaitu dengan fungsi kognitif terganggu dan normal. Pemeriksaan fungsi kognitif menggunakan tes Mini-Cog, jika hasil $<3$ dianggap mengalami fungsi kognitif terganggu. Kadar p-tau serum diukur dengan metode enzyme-linked immunosorbent assay (ELISA). Hasil dinyatakan dalam satuan $\mathrm{ng} / \mathrm{L}$ dengan rentang nilai yang dapat dideteksi adalah 2-600ng/L dan sensitivitas mencapai 0,08ng/L.

Usia dikelompokkan menjadi 40-55 tahun dan $>55-60$ tahun dengan mengambil nilai tengah (central tendency). Adapun pendidikan dibagi berdasarkan tamat sekolah dasar ( $\leq 6$ tahun) atau sekolah yang lebih tinggi lagi ( $>6$ tahun). Lama paparan pestisida dikategorikan pada pemakaian lebih dari atau kurang dari 10 tahun. Adapun penggunaan batas nilai 10 tahun berdasarkan pada referensi sebelumnya yang menjelaskan bahwa puncak terjadinya gangguan fungsi kognitif adalah setelah terpapar organofosfat selama sepuluh tahun. Penurunan fungsi kognitif diprediksi akan terus mengalami penurunan setiap tahun setalah melewati sepuluh tahun. Paparan kronis organofosfat disebutkan merusak vaskularisasi serebral dan terutama menyebabkan gangguan fungsi memori dan belajar. ${ }^{9} 10$ Paparan pestisida organofosfat kronik didefinisikan sebagai riwayat terpapar pestisida organofosfat secara langsung, baik pada proses pencampuran atau penyemprotan pestisida, maupun pembersihan alat aplikator pestisida dalam kurun waktu minimal 2 tahun. Pestisida adalah semua substansi atau campuran substansi kimia atau biologis yang betujuan untuk mengusir, membunuh, dan mengontrol hama, serta meregulasi pertumbuhan tanaman. ${ }^{8}$ Penentuan penggolongan bahan aktif pestisida adalah dengan cara menyesuaikan nama formulasi yang tercantum pada kemasan pestisida yang digunakan oleh subjek penelitian dengan daftar pestisida menurut Direktorat Pupuk dan Pestisida Kementerian Pertanian Republik Indonesia tahun $2016 .{ }^{11}$
Penelitian ini disetujui oleh komite etik penelitian Fakultas Kedokteran Universitas Udayana dengan nomor 2568/UN.14.2.2.VII.14/LP/2018. Analisis statistik menggunakan SPSS versi 20. Analisis univariat dilakukan untuk mengetahui karakteristik setiap variabel; analisis bivariat dengan uji Chi-square dan uji Fisher. Analisis mulivariat menggunakan metode regresi logistik dan analisis jalur untuk mengetahui jalur yang digunakan oleh paparan pestisida organofosfat kronik dalam memengaruhi fungsi kognitif. Digunakan pula metode statistik receiver operating characteristic (ROC) dan area under the curve (AUC) untuk mengetahui nilai ambang batas normal kadar protein p-tau serum dan kemampuannya dalam mendeteksi gangguan kognitif.

\section{HASIL}

Terdapat 66 subjek yang diklasifikasikan menjadi kelompok kasus kelompok kontrol, masingmasing 33 orang dalam penelitian ini (Tabel 1). Sebagian besar subjek adalah perempuan $(60,6 \%)$

Tabel 1. Karakteristik Dasar Subjek Penelitian $(\mathrm{n}=66)$

\begin{tabular}{lc}
\hline \multicolumn{1}{c}{ Variabel } & n (\%) \\
\hline Usia & \\
- $40-55$ tahun & $34(51,5)$ \\
- $55-60$ tahun & $32(48,5)$ \\
Jenis Kelamin & \\
- Laki-laki & \\
- Perempuan & $26(39,4)$ \\
Pendidikan & $40(60,6)$ \\
- $\leq 6$ tahun & \\
- >6 tahun & $47(71,2)$ \\
Merokok & $19(28,8)$ \\
- Ya & \\
- Tidak & $14(21,2)$ \\
Alkohol & $52(78,8)$ \\
- Ya & \\
- Tidak & $4(6,1)$ \\
Frekuensi Paparan & $62(93,9)$ \\
- $\geq 3$ kali/minggu \\
- <3 kali/minggu \\
Durasi Paparan \\
- $\geq 10$ tahun \\
- <10 tahun \\
Jenis \\
- Organofosfat saja \\
- Organosfosfat dan jenis lain \\
\hline
\end{tabular}




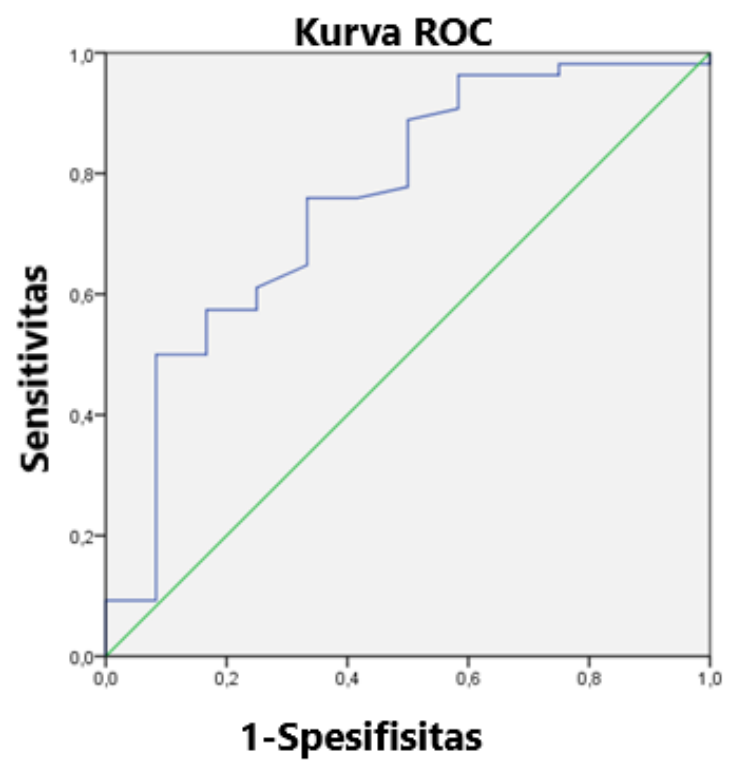

Gambar 1. Hasil Prosedur Receiver Operating Characteristic (ROC) Kadar Protein P-tau Serum dengan Fungsi Kogntif.

dan berlatar belakang pendidikan formal $\leq 6$ tahun (71,2\%). Sebanyak 45,5\% subjek penelitian menggunakan jenis pestisida organofosfat dan jenis lainnya dengan rerata durasi paparan 12,98 (2-40) tahun.

Hasil dari koordinat ROC menunjukkan nilai ambang batas kadar protein p-tau serum pada penelitian ini adalah $78,67 \mathrm{ng} / \mathrm{L}$ dengan sensitivitas $75,9 \%$ dan spesifisitas 67,0\% (Gambar 1). Dengan demikian, kadarnya diklasifikasikan menjadi tinggi $(\geq 78,67 \mathrm{ng} / \mathrm{mL})$ dan serum normal $(<78,67 \mathrm{ng} / \mathrm{mL})$. Adapun median kadar p-tau serum subjek penelitian ini adalah 97,27 (49,10-4004,65ng/mL) yang berarti termasuk kategori tinggi.

Tabel 2 menunjukkan subjek dengan lama paparan pestisida $\geq 10$ tahun memiliki kadar protein p-tau serum yang lebih tinggi dibandingkan dengan yang $<10$ tahun secara bermakna $(\mathrm{p}=0,003)$.

Tabel 2. Perbandingan Kadar P-tau Berdasarkan Lama Paparan Pestisida $(n=66)$

\begin{tabular}{|c|c|c|c|}
\hline \multirow[b]{2}{*}{ Variabel } & \multicolumn{2}{|c|}{ Lama Paparan } & \multirow[b]{2}{*}{$\mathbf{p}^{*}$} \\
\hline & $\begin{array}{l}\geq 10 \text { tahun } \\
\quad \text { n }(\%)\end{array}$ & $\begin{array}{c}<10 \text { tahun } \\
\text { n (\%) }\end{array}$ & \\
\hline \multicolumn{4}{|l|}{ Kadar P-tau } \\
\hline - Tinggi & $33(63,5)$ & $19(36,5)$ & 0,003 \\
\hline - Normal & $6(42,9)$ & $8(57,1)$ & \\
\hline
\end{tabular}

Tabel 3 menunjukkan hasil analisis multivariat hubungan antara berbagai faktor risiko dengan fungsi kognitif. Pada kelompok subjek yang mengalami gangguan kognitif, sebanyak 87,9\% mengalami paparan pestisida selama $\geq 10$ tahun dan $97 \%$ mempunyai kadar p-tau serum yang tinggi. Kedua variabel tersebut berpengaruh terhadap fungsi kognitif, yaitu lama paparan pestisida (RO 17,57, IK 95\% 0,016-0,221; $\mathrm{p}<0,001)$ dan kadar protein $\mathrm{p}$-tau serum (RO 8,57; IK 95\% 2,64-194,83; p=0,003). Selanjutkan dibuatkan sebuah pola untuk mengetahui jalur kausal kedua variabel terhadap fungsi kognitif.

Koefisien jalur lama paparan pestisida terhadap fungsi kognitif 0,402 dan koefisien jalur kadar p-tau serum terhadap fungsi kognitif adalah 0,332 (Gambar 2). Berdasarkan analisis jalur didapatkan bahwa kekuatan pengaruh langsung lama paparan pestisida terhadap fungsi kognitif adalah $16,1 \%$. Adapun besar kekuatan pengaruh lama paparan pestisida terhadap fungsi kognitif melalui peningkatan kadar protein p-tau serum adalah sebesar $6,2 \%$.

\section{PEMBAHASAN}

Sebanyak $87 \%$ subjek penelitian ini mengalami gangguan fungsi kognitif telah terpapar lebih dari 10 tahun. Lama paparan pestisida lebih dari 10 tahun berisiko 17 kali menyebabkan gangguan fungsi kognitif dibandingkan subjek yang terpapar kurang dari 10 tahun setelah mengontrol variabel usia dan pendidikan. Hasil penelitian ini sesuai dengan Mattson dkk bahwa subjek dengan paparan dosis rendah selama 10 tahun merupakan lama puncak terjadinya gangguan kognitif dan setelah melewati tahun ke-10 diprediksi fungsi tersebut akan mengalami penurunan setiap tahunnya. ${ }^{12}$

Patofisologi paparan organofosfat kronik menyebabkan gangguan fungsi kognitif meliputi beberapa teori. Paparan organosfosfat kronik akan menimbulkan peningkatan stres oksidatif sehingga memicu terjadinya inflamasi vaskular dan disfungsi vaskular. Disfungsi vaskular terutama ditemukan pada arteri serebral media dan berhubungan dengan kerusakan neuron-neuron hipokampus. ${ }^{13}$ Paparan organofosfat jangka panjang akan memicu pembentukan aterosklerosis pada arteri serebral sehingga terjadinya disfungsi vaskular dan menyebab- 
Tabel 3. Hubungan Faktor Risiko terhadap Fungsi Kognitif (n=66)

\begin{tabular}{|c|c|c|c|c|c|}
\hline \multirow[b]{2}{*}{ Variabel } & \multicolumn{2}{|c|}{ Fungsi Kognitif } & \multirow[b]{2}{*}{ RO } & \multirow[b]{2}{*}{ IK 95\% } & \multirow[b]{2}{*}{$\mathbf{p}$} \\
\hline & $\begin{array}{c}\text { Terganggu } \\
\text { n (\%) }\end{array}$ & $\begin{array}{c}\text { Normal } \\
\text { n }(\%) \\
\end{array}$ & & & \\
\hline $\begin{array}{l}\text { Usia } \\
\text { - } \quad 40-55 \text { tahun } \\
\text { - }>55 \text { tahun }\end{array}$ & $\begin{array}{l}13(39,4) \\
20(60,6)\end{array}$ & $\begin{array}{l}21(63,6) \\
12(36,4)\end{array}$ & 0,371 & $0,137-1,005$ & $0,084 *$ \\
\hline $\begin{array}{l}\text { Jenis Kelamin } \\
\text { - } \quad \text { Laki-laki } \\
\text { - } \quad \text { Perempuan }\end{array}$ & $\begin{array}{l}12(36,4) \\
21(63,6)\end{array}$ & $\begin{array}{l}14(42,4) \\
19(57,6)\end{array}$ & 0,776 & $0,288-2,087$ & $0,801^{*}$ \\
\hline $\begin{array}{l}\text { Pendidikan } \\
-\quad \leq 6 \text { tahun } \\
-\quad>6 \text { tahun }\end{array}$ & $\begin{array}{c}27(81,8) \\
6(18,2)\end{array}$ & $\begin{array}{l}20(60,6) \\
13(39,4)\end{array}$ & 2,925 & $0,948-9,028$ & $0,102 *$ \\
\hline $\begin{array}{l}\text { Merokok } \\
\text { - } \quad \text { Ya } \\
\text { - } \quad \text { Tidak }\end{array}$ & $\begin{array}{c}7(21,2) \\
26(78,8)\end{array}$ & $\begin{array}{c}7(21,2) \\
26(78,8)\end{array}$ & 1,000 & $0,307-3,255$ & $1,000^{*}$ \\
\hline $\begin{array}{l}\text { Alkohol } \\
\text { - } \quad \text { Ya } \\
\text { - } \quad \text { Tidak }\end{array}$ & $\begin{array}{c}2(6,1) \\
31(93,9)\end{array}$ & $\begin{array}{c}2(6,1) \\
31(93,9)\end{array}$ & 1,000 & $0,132-7,555$ & $1,000^{*}$ \\
\hline $\begin{array}{l}\text { Frekuensi Paparan Pestisida } \\
\text { - } \quad \geq 3 \mathrm{kali} / \mathrm{minggu} \\
\text { - } \quad<3 \mathrm{kali} / \mathrm{minggu}\end{array}$ & $\begin{array}{l}11(33,3) \\
22(66,7)\end{array}$ & $\begin{array}{l}12(36,4) \\
21(63,6)\end{array}$ & 0,875 & $0,31-2,41$ & $0,500 *$ \\
\hline $\begin{array}{l}\text { Lama Paparan Pestisida } \\
\text { - } \quad \geq 10 \text { tahun } \\
\text { - } \quad<10 \text { tahun }\end{array}$ & $\begin{array}{c}29(87,9) \\
4(12,1)\end{array}$ & $\begin{array}{l}10(30,3) \\
23(69,7)\end{array}$ & 16,675 & $4,626-60,105$ & $0,000 * *$ \\
\hline $\begin{array}{l}\text { Jenis Pestisida } \\
\text { - Organofosfat saja } \\
\text { - Organosfosfat dan jenis lain }\end{array}$ & $\begin{array}{l}19(57,6) \\
14(42,4)\end{array}$ & $\begin{array}{l}17(51,5) \\
16(48,5)\end{array}$ & 1,277 & $0,484-3,372$ & $0,403 * *$ \\
\hline $\begin{array}{l}\text { Kadar P-tau } \\
\text { - } \quad \text { Tinggi } \\
\text { - } \quad \text { Normal }\end{array}$ & $\begin{array}{c}32(97,0) \\
1(3,0)\end{array}$ & $\begin{array}{l}20(60,6) \\
13(39,4)\end{array}$ & 20,8 & $2,524-171,440$ & $0,000 *$ \\
\hline
\end{tabular}

*Uji Chi-square; ** Uji Fisher; RO: rasio Odds; IK; interval kepercayaan.

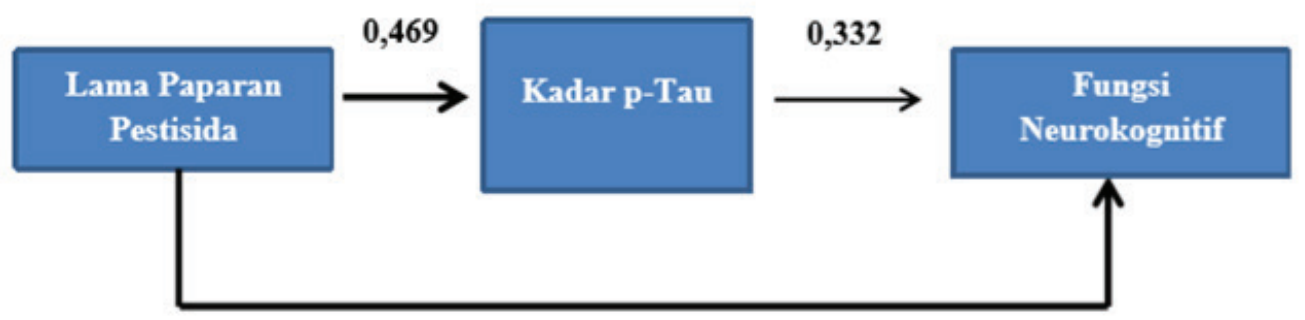

$\mathbf{0 , 4 0 2}$

Gambar 2. Struktur Hubungan Kausal antara Variabel Lama Paparan Pestisida dan Kadar Protein P-tau Serum terhadap Fungsi Kognitif

kan penurunan suplai ke area otak kemudian berakibat gangguan kognitif vaskular. ${ }^{13}$

Organofosfat juga memprovokasi perubahan histologis di hipokampus, seperti hilangnya neuron, penyusutan neuron, edema pada sel piramidal hipokampus, infiltrasi sel inflamasi dan proliferasi sel astroglia berlebihan. Neuron-neuron hipokampus juga tampak lebih kecil dan struktur membrannya mengalami kerusakan dengan inti yang menyusut dan kromatin yang teragregasi ke tepi. Peningkatan jumlah badan golgi, edema dan kerusakan mitokondria pada hipokampus. ${ }^{14}$ Penumpukan stres oksidatif 
selain menyebabkan disfungsi vaskular, juga akan meningkatkan respons neuroinflamasi, gangguan depolarisasi kanal natrium kalium, dan mengganggu homesotatis kalsium, sehingga menyebabkan disfungsi neurotransmiter dan hilangnya sel neuron serta sinaps secara progresif. ${ }^{13}$

Hasil analisis perbandingan kadar protein p-tau serum berdasarkan lama paparan menunjukkan subjek dengan lama paparan pestisida lebih dari 10 tahun memiliki kadar protein $\mathrm{p}$-tau serum yang lebih tinggi dibandingkan subejk dengan paparan pestisida kurang dari 10 tahun. Sebuah penelitian uji coba pada tikus yang diinjeksi organofosfat jenis diisopropilfluorofosfat (DFP) didapatkan 15,5 2 kali berisiko menyebabkan peningkatan hiperfosforilasi protein tau di area striatum dan 21,5 $\pm 1,3$ kali di area hipokampus. ${ }^{15}$

Rentang kadar p-tau pada penelitian ini cukup lebar. Hal ini dapat dikaitkan dengan etiologi dari proses tauopati. Adapun proses tauopati berkaitan dengan penyakit neurodegeneratif seperti parkinson, demensia, dan penyakit motor neuron, faktor lingkungan, serta genetik. Beberapa upaya untuk mengurangi bias terkait dengan kadar p-tau telah dilakukan. Peneliti menetapkan kriteria rentang usia sampel. Peneliti juga telah memasukkan penyakit neurodegeneratif sebagai kriteria eksklusi. Faktor genetik yang juga memiliki peranan penting dalam proses tauopati tidak dapat dieksklusi oleh peneliti karena membutuhkan media pemeriksaan lebih lanjut.

Paparan organofosfat dalam jangka waktu panjang akan menyebabkan residu metabolit organofosfat dalam jaringan tubuh menyebabkan proses aktivasi mikroglia dan memicu terjadinya inflamasi pada neuron, kemudian meningkatkan fosforilasi protein tau. ${ }^{14}$ Paparan organofosfat kronik dosis rendah juga dapat menyebabkan modifikasi pada struktur mikrotubul pada sel neuron di otak. Penelitian uji coba pada ayam betina yang diinjeksikan klorpirifos $150 \mathrm{mg}$ per kilogram berat badan dan ditemukan proses inhibisi pada aktivitas mitochondrial complex I dan penurunan jumlah ATP. ${ }^{14}$

Proses tauopati dan inhibisi mitokondria memiliki hubungan kausal dua arah. Disfungsi mitokondria akan menyebabkan kematian sel neuron dan menyebabkan fosforilasi dan agregasi protein Tau. Hiperfosforilasi tau kemudian akan kembali menyebabkan kerusakan mitokondria melalui gangguan transpor mitokondria, dinamis, serta kerusakan fungsi mitokondria. Mitokondria berfungsi untuk menyiapkan energi yang dibutuhkan oleh sel neuron. Transpor mitokondria dimediasi oleh protein tau, dan bersama-sama dengan protein tau akan melewati akson menuju sinaps. Ekspresi yang berlebihan dari protein tau dan hiperfosforilasi protein tau akan menyebabkan gangguan distribusi mitokondria dan kerusakan mitokondria ini akan kembali menyebabkan hiperfosforilasi protein tau. ${ }^{16}$

Paparan organofosfat jangka panjang akan menyebabkan peningkatan stres oksidatif kronik baik melalui pelepasan mediator inflamasi maupun berasal dari disfungsi mitokondria, kemudian meningkatkan aktivitas GSK-3 $\beta$ dan menginduksi hiperfosforilasi protein tau. ${ }^{17}$ Astrosit yang teraktivasi akibat paparan organofosfat kronik kemudian akan memediasi terbentuknya produk oksidatif asam lemak yang memicu hiperfosforilasi protein tau. ${ }^{18}$ Penurunan aktivitas rantai pernapasan mitokondria khususnya kompleks I terlibat dalam etiologi penyakit neurodegeneratif dengan dimediasi oleh dominasi alfa serebral sinuklein atau protein tau patologis. Tingkat imunoreaktivitas tau yang abnormal tinggi ditemukan dalam sitoplasma neuron, oligodendrosit, dan astrosit. Secara ultrastruktural bahan tau imunoreaktif terdiri dari filamen lurus $15 \mathrm{~nm}$ yang dilengkapi oleh antibodi terhadap tau terfosforilasi. Sel dengan abnormalitas tau imunoreaktif mengandung activated caspase 3 yang berasosiasi dengan kematian sel neuron. ${ }^{18}$

Penelitian ini mendapatkan subjek dengan kadar protein $\mathrm{p}$-tau serum yang tinggi memiliki kecenderungan 20 kali untuk mengalami gangguan fungsi kognitif dibandingkan subjek dengan kadar protein p-tau serum normal. Hubungan protein tau dengan fungsi kognitif telah banyak dibuktikan. Protein tau merupakan salah satu penanda biologis adanya lesi di sel neuron dan glia akibat proses neurodegenerasi. Patofisiologi 
protein tau menyebabkan gangguan fungsi kognitif melalui proses hiperfosforilasi. Hiperfosforilasi protein tau menyebabkan kerusakan integritas sel neuron. Protein tau kemudian akan terlepas dari mikrotubul dan terakumulasi menjadi peptida tau yang bersifat toksik dan bisa ditemukan pada cairan serebrospinal maupun serum. ${ }^{19}$ Terdeteksinya protein tau menandakan adanya kematian sel neuronal atau disfungsi seluler. Gangguan fungsi kognitif khususnya penyakit Alzheimer telah diteliti dan ditemukan protein tau terfosforilasi banyak terakumulasi di area hipokampus, korteks entorhinal, amygdala, dan nukleus raphe dorsal. ${ }^{20}$

Hiperfosforilasi protein tau disebutkan berkorelasi kuat dengan penurunan ekspresi protein presinaps pada pasien Alzheimer. ${ }^{21}$ Penelitian lain dilakukan pada tahun 2016 pada 39 pasien penyakit Alzheimer, 37 pasien MCI, dan 37 individu normal. Hasil penelitian ini menemukan bahwa konsentrasi protein $\mathrm{p}$-tau serum secara signifikan lebih tinggi pada kelompok dengan penyakit Alzheimer dibandingkan kelompok MCI, dan lebih tinggi dibandingkan kelompok individu normal. Penelitian ini juga menunjukkan adanya korelasi negatif berkekuatan sedang antara kadar protein p-tau serum dengan skor $\operatorname{MMSE}(-0,4273)$ dan skor MoCA $(-0,4613) .{ }^{19}$

Berdasarkan hasil analisis jalur didapatkan model bahwa lama paparan pestisida organofosfat dapat menyebabkan gangguan fungsi kognitif secara partially mediated melalui peningkatan kadar protein $\mathrm{p}$-tau serum. Lama paparan pestisida organofosfat juga dapat menyebabkan gangguan fungsi kognitif secara langsung. Hal ini sesuai dengan studi yang mendemonstrasikan bahwa variabel paparan organofosfat yang dapat secara langsung memengaruhi fungsi kognitif adalah lama paparan. Lama paparan organofosfat dikatakan bertanggung jawab langsung dengan efek samping yang dihasilkan. ${ }^{22}$

Besar kekuatan pengaruh lama paparan pestisida organofosfat kronik lebih besar melalui pengaruh langsung yaitu $16 \%$ dibandingkan melalui peningkatan protein p-Tau serum, yaitu $6,2 \%$. Pengaruh lama paparan secara langsung maupun pengaruh lama paparan melalui peningkatan protein tau sama-sama berkekuatan lemah tetapi kedua pengaruh tersebut bermakna secara statistik dan nilai koefisien jalur di atas 0,005 atau secara proporsional pengaruhnya di atas 5\% sehingga kedua pengaruh ini dapat dipertimbangkan sebagai model kausal antara paparan organofosfat dan fungsi kognitif.

Kelemahan penelitian ini adalah terdapat beberapa variabel yang tidak diteliti yaitu kadar organofosfat yang digunakan oleh subjek penelitian, biomarker yang dapat memprediksi kadar metabolit organofosfat sehingga dapat memastikan hasil wawancara dengan subjek penelitian terkait riwayat penggunaan pestisida. Penelitian ini juga tidak memasukkan mediator inflamasi serta kadar beta amiloid yang juga diprediksi sebagai jalur mediator antara paparan pestisida organofosfat dengan fungsi kognitif. Turunan organofosfat yang digunakan oleh subjek penelitian tidak diidentifikasi pada studi ini, sehingga mekanisme untuk menyebabkan gangguan fungsi kognitif dapat melalui mekanisme lain selain peningkatan protein $\mathrm{p}$-tau serum.

\section{KESIMPULAN}

Paparan kronik pestisida jenis organofosfat meningkatkan risiko terjadinya gangguan fungsi kognitif secara parsial dimediasi oleh protein fosforilasi tau serum tinggi.

\section{DAFTAR PUSTAKA}

1. Killin OJ, Starr JM, Ivy JS, Russ, TC. Environmental risk factors for dementia: a systematic review. BMC Geriatrics. 2016;16:175.

2. Yegambaram M, Bhagyashree M, Thomas GB, Rolf UH. Environmental contaminants and Alzheimer's disease. Current Alzheimer Research. 2015;12(2):116-46.

3. Corral VA, Natalia S, Liliana ZV, Pablo AG, Floria P. Cognitive impairment in agricultural workers and nearby residents exposed to pesticides in the Coquimbo Region of Chile. Neurotoxicology and Teratology. 2017;62:13-9.

4. Munoz-Quezada, MT, Lucero B, Iglesias V, Munoz MP, Achu E, Cornejo C, dkk. Chronic exposure to organophosphate (OP) pesticides and neuropsychological functioning in frm workers: a review. Int J Environ Health Res. 2017;27(1):82-93.

5. Damalas AC, Koutroubus SD. Farmers exposure to pesticides: toxicity types and ways of prevention. Toxics. 2015;4(1):1. 
6. Badan Pusat Statistik. Laporan bulanan data sosial ekonomi. Edisi 94. Jakarta: Badan Pusat Statistik; 2018.

7. Saputri DR, Hanani Y, Yunita NA. Hubungan penggunaan dan penanganan pestisida pada petani bawang merah terhadap residu pestisida dalam tanah di lahan pertanian desa Wanasari kecamatan Wanasari kabupaten Brebes. Jurnal Kesehatan Masyarakat. 2016;4(3):879-87.

8. Direktorat Pupuk dan Pestisida. Pestisida. Jakarta: Kementrian Pertanian Republik Indonesia; 2016.

9. Li P, Yin YL, Zhu ML, Pan GP, Zhao FR, Lu JX, dkk. Chronic administration of isocarbophos induces vascular cognitive impairment in rats. J Cell Mol. Med. 2016; 20(4):731-9.

10. Yan D, Zhang Y, Liu L, dan Yan H. Pesticide exposure and risk of Alzheimer's disease : a systematic review and meta-analysis. Sci Rep. 2016; 6:32222.

11. Direktorat Pupuk dan Pestisida. Pestisida. 2016. Jakarta: Kementrian Pertanian Republik Indonesia.

12. Mattson N, Zetterberg H, Insel PS, Andreasson U, Stomru E, Palmqvist S, dkk. Plasma tau in Alzheimer disease. Neurology. 2016;6(87):1-9.

13. Kim SA, Lee YM, Lee HW, Jacobs DRJ, Lee DH. Greater cognitive decline with aging among elders with high serum concentrations of organochlorine pesticides. PLoS ONE. 2015;10(6):e0130623.

14. Li G. Common pesticide, dichlorodiphenyltrichloroethane (DDT), increases amyloid-beta levels by impairing the function of ABCA1 and IDE: implication for Alzheimer's disease. JAD. 2015;10:109-22.

15. Saravi SS, Dehpour AR. Potential role of organochlorine pesticides in the pathogenesis of neurodevelopmental, neurodegenerative, and neurobehavioral disorders: a review. Life Sci. 2015;11:255-64.

16. Schopfer LM, Lockridge O. Chlorpyrifos oxon promotes tubulin aggregation via isopeptide crosslinking between diethoxyphospho-Lys and Glu or Asp; implications for neurotoxicity. J Biol Chem Papers in Press. 2018;293(35):13566-77.

17. Yamada K, Patel TK, Hochgrafe K, Mahan TE, Jiang $\mathrm{H}$, Stewart FR, dkk. Analysis of in vivo turnover of tau in a mouse model of tauopathy. Mol. Neurodegener. 2015;10:55

18. Yadav SS, Singh MK, Yadav RS. Organophosphate induced Alzheimer's disease: an epigenetic disease. Journal of Clinical Epigenetics. 2016;2:1-10.

19. Wang ZX, Tan L, Yu JT. Axonal transport defects in Alzheimer's disease. Mol Neurobiol. 2015;51(3):1309-21.

20. Qi H, Prabakaran S, Cantrelle FX, Chambraud B, Gunawardema J. Characterization of neuronal tau protein as a target of extracellular signalregulated kinase. J Biol Chem. 2016;291(14):7742-53.

21. Kaniyappan S, Chandupatla RR, Mandelkow EM, Mandelkow E. Extracellular low-n oligomers of tau cause selective synaptotoxicity without affecting cell viability. Alzheimers Dement. 2017;3:1270-91.

22. Shekhar S, Kumar R, Rai N, Kumar V, Singh K, Upadhyay AD. Estimation of tau and phosphorylated tau 181 in serum of Alzheimer's disease and mild cognitive impairment patients. PloS ONE. 2016;11(7):e0159099. 